\title{
Сучасні уявлення про комплексне застосування засобів відновлення у програмах фізичної реабілітації спортсменів з травмами нижніх кінцівок
}

\author{
удК 796:616.748-085 \\ Шаді Абделбасет Мохаммад Алхуб, \\ Джафар Тайсір Мохаммад Аль-Куран, \\ О. К. Ніканоров
}

Національний університет фізичного виховання і спорту України, Київ, Україна

\begin{abstract}
Резюме. У статті наведено дані щодо поширення спортивних травм та сучасних тенденцій застосування різноманітних засобів фізичної реабілітації. Мета. Здійснити аналіз науковометодичної літератури щодо комплексного застосування у програмах фізичної реабілітації найбільш ефективних засобів відновлення спортсменів. Методи. Аналіз та узагальнення спеціальної науково-методичної літератури з питань фізичної реабілітації спортсменів. Результати. Встановлено, що найпоширенішими у різних видах спорту є травми нижніх кінцівок. Сучасна патогенетично-обґрунтована фізична реабілітація спортсменів 3 травмами опорно-рухового апарату нижніх кінцівок насамперед має бути забезпечена поєднаним застосуванням різних способів консервативного та оперативного лікування і диференціюватися залежно від локалізації травми, її механізму, характеру пошкодження, термінів репаративної регенерації травмованих тканин, періоду відновлення, віку, статі, спортивного стажу, а також специфіки обраного виду спорту. Висновки. Враховуючи необхідність максимально швидкого повернення до тренувальної та змагальної діяльності та максимально ефективного і повного відновлення рухової функції травмованої нижньої кінцівки, одним із перспективних напрямів розвитку реабілітаційних програм $€$ комплексне використання засобів відновлення. Їх застосування дозволить знизити терміни непрацездатності та досягти якісних позитивних змін у процесі одужання.

Ключові слова: фізична реабілітація, спортсмен, травма, нижні кінцівки, відновлення.
\end{abstract}

Современные представления о комплексном применении средств восстановления в программах физической реабилитации спортсменов с травмами нижних конечностей Шади Абделбасет Мохаммад Алхуб, Джафар Тайсир Мохаммад Аль-Куран, А. К. Никаноров

Резюме. В статье приведены данные о распространении спортивных травм и современных тенденциях применения различных средств физической реабилитации. Цель. Провести анализ научно-методической литературы по вопросу комплексного применения в программах физической реабилитации наиболее эффективных средств восстановления спортсменов. Методы. Анализ и обобщение специальной научно-методической литературы по вопросам физической реабилитации спортсменов. Результаты. Установлено, что наиболее распространенными в разных видах спорта являются травмы нижних конечностей Современная патогенетически-обоснованная физическая реабилитация спортсменов с травмами опорно-двигательного аппарата нижних конечностей прежде всего должна быть обеспечена совмещенным применением различных способов консервативного и оперативного лечения и дифференцироваться в зависимости от локализации травмы, ее механизма, характера повреждения, сроков репаративной регенерации травмированных тканей, периода восстановления, возраста, пола, спортивного стажа, а также специфики избранного вида спорта. Выводы. Учитывая необходимость максимально быстрого возвращения к тренировочной и соревновательной деятельности и максимально эффективного и полного восстановления двигательной функции травмированной нижней конечности, одним из перспективных направлений развития реабилитационных программ является комплексное использование средств восстановления. Их применение позволит снизить сроки нетрудоспособности и достичь качественных позитивных изменений в процессе выздоровления.

Ключевые слова: физическая реабилитация, спортсмен, травма, нижние конечности, восстановление. 


\section{Contemporary notions about complex usage of recovery means in physical rehabilitation programs for athletes with the lower extremity injuries Shadi Abdelbaset Mohammad Alhub, Jafar Taysir Mohammad Al-Kuran, O. K. Nikanorov}

Abstract. The article presents data on sports injuries prevalence and modern trends of using various physical rehabilitation means. Objective. To analyze scientific and methodical literature on the complex application in the programs of physical rehabilitation of the most effective means for athlete recovery. Methods. Analysis and generalization of special scientific and methodical literature on physical rehabilitation of athletes. Results. It has been found that the lower extremity injuries are the most widespread in various sports events. Modern pathogenetically grounded physical rehabilitation of athletes with injuries of the locomotorium of the lower extremities should be ensured, first of all, by combined usage of different methods of conservative and operative treatment and differentiated depending on injury localization, its mechanism, the nature of the damage, the terms of the reparative regeneration of injured tissues, the recovery period, age, gender, sports experience, as well as the specifics of the chosen sports event. Conclusions. Taking into account the necessity of the fastest return to training and competitive activities and the maximum effective and complete restoration of the motor function of injured lower extremity, one of the promising directions of rehabilitation programs development is the complex usage of recovery means. Their application will allow to reduce the terms of disability and achieve qualitative positive changes in the process of recovery. Keywords: physical rehabilitation, athlete, injury, lower extremities, recovery.

Постановка проблеми. В умовах професіоналізації та комерціалізації спорту інтенсивна тренувальна та змагальна діяльність призводить до хронічного перевантаження локомоторного апарату i, як наслідок, до виникнення різних травм у спортсменів [2, 5, 9]. У загальній структурі травматизму спортивні травми становлять від 10 до $17 \%$ всіх пошкоджень [15, 17]. Спортсмени високого класу через професійні захворювання і травми змушені пропускати від 7 до $45 \%$ тренувальних занять і від 5 до $35 \%$ змагальних стартів $[4,9]$.

Пошкодження опорно-рухового апарату у спортивній практиці дуже різноманітні і зазвичай вимагають диференційованого підходу у визначенні тактики лікування і подальшого відновного процесу. У разі виникнення травми виникають як анатомічні, так і фрункціональні порушення, які обмежують можливість самообслуговування, забезпечення побутових потреб i професійну працездатність спортсмена. Дані сучасних досліджень свідчать, що спортсмени у різних видах спорту найчастіше пошкоджують нижні кінцівки $[11,13,21]$.

Успіх відновлення спортсмена після травми і повернення до повноцінної тренувальної та змагальної діяльності більше ніж на половину залежить не тільки від якісно проведеного лікування, але й від грамотно спланованого та побудованого реабілітаційного процесу $[1,3,5$, 10]. Фізична реабілітація спортсменів з травмами нижніх кінцівок $є$ багатогранним завданням, тому що вимагає, з одного боку, максимально швидкого повернення до тренувальної та змагальної діяльності, а з іншого - максимально ефективного і повного відновлення рухової функції 3 урахуванням підвищених професійних вимог до рівня фрункціонування опорно-рухового апарату. У цьому зв'язку, раціональний добір і комплексне застосування найбільш ефективних сучасних засобів фрізичної реабілітації відповідно до нових технологій оперативного та консервативного лікування ушкоджень опорно-рухового апарату спортсмена ставлять значний інтерес.

Зв'язок теми 3 науковими та практичними завданнями. Робота виконана відповідно до Зведеного плану НДР у сфері фрізичної культури та спорту на 2011-2015 рр. за темою 4.4: «Удосконалення організаційних і методичних основ програмування процесу фрізичної реабілітації при дисфункціональних порушеннях у різних системах організму людини» (номер держреєстрації 0111U001737) та Плану НДР НУФВСУ на 2016-2020 рр. за темою 4.2: «Організаційні та теоретико-методичні основи фрізичної реабілітації осіб різних нозологічних, професійних та вікових груп» (номер держреєстрації 0116U001609).

Мета дослідження - здійснити аналіз сучасної науково-методичної літератури щодо комплексного застосування найбільш ефективних засобів відновлення спортсменів у програмах фрізичної реабілітації.

Аналіз останніх досліджень із цієї проблеми. У вітчизняній та іноземній науково-методичній літературі останніх років широко дискутується питання про раціональне застосування після різноманітних спортивних травм комплексів сучасних засобів фрізичної реабілітації, їх ефрективність, терміни призначення, тривалість використання, критерії повернення до тренувальної діяльності [8, 11-14, 18].

Більшість вчених, які працюють у сфері відновлення спортсменів з травмами опорно-рухового 
апарату [2, 5, 6, 10, 17, 21], відзначають, що сучасна патогенетично-обгрунтована фрізична реабілітація даного контингенту насамперед має бути забезпечена поєднаним застосуванням різних методів консервативного й оперативного лікування та диференціюватися залежно від локалізації травми, її механізму, характеру пошкодження та періоду відновлення.

У зарубіжній літературі за останні 10 років уявлення про фрізичну реабілітацію після травм нижніх кінцівок зазнало значних змін [13, 20, 21]. Для усунення больового синдрому використовують кріоманжети та кріоспреї [16], для відновлення рухливості та ліквідації контрактур у суглобах - апарати тривалих пасивних рухів [19], для профрілактики м'язової гіпотрофрії електростимуляцію протягом перших 7-10 днів після оперативного втручання [17].

Проведений аналіз даних спеціальної науково-методичної літератури показав, що основними завданнями, які стоять перед лікарями і фахівцями у фрізичній реабілітації у процесі відновлення спортсменів з ушкодженням нижніх кінцівок, $\epsilon$ $[2,5,7,12,18]$ :

- забезпечення максимально можливих умов для нормального перебігу порушених реституційно-регенеративних процесів у травмованому сегменті кінцівки;

- призначення комплексної медикаментозної терапії та програм відновлення для нормалізації порушеного обміну речовин індивідуально для кожного пацієнта;

- запобігання, а за необхідності - своєчасна ліквідація пролежнів, гіпотроорії м'язів, контрактур;

- профілактика та відновне лікування ускладнень з боку серцево-судинної та дихальної систем;

- проведення ранньої та пізньої психологопедагогічної реабілітації: комплексне поєднання нормалізуючого впливу фрізичних вправ з педагогічним впливом; поступове зміцнення і розвиток у спортсмена віри в свої сили, стійкості в період перенесення больових відчуттів і дискоморорту, мужності під час оперативного втручання, наполегливості в подоланні виникаючих функціональних розладів;

- відновлення порушених рухових умінь і навичок, у тому числі спеціальних, самостійного пересування та ін.;

- профресійне навчання, а за необхідності і перенавчання;

- повна соціальна, побутова та професійна реабілітація.

Таким чином, виявлення найбільш ефективних та раціональних засобів відновлення ушкодженої рухової фрункції нижніх кінцівок у спортсменів, спрямованих на мінімізацію післяопераційних ускладнень, скорочення строків відновлення, підвищення функціональних можливостей нервовом'язового апарату, профрілактику рецидивних травм, продовжує залишатися актуальною проблемою сучасної фрізичної реабілітації.

Методи дослідження: аналіз та узагальнення зарубіжної та вітчизняної спеціальної науково-методичної літератури з питань фрізичної реабілітації спортсменів з пошкодженням опорно-рухового апарату нижніх кінцівок, що дозволило, враховуючи механізми порушення рухової фрункції та ґрунтуючись на теорії та методиці фрізичного виховання та фрізичної реабілітації, визначити перспективи комплексного застосування сучасних засобів відновлення.

Результати дослідження та їх обговорення. Проблема фрізичної реабілітації спортсменів при травмах нижніх кінцівок дуже складна і вимагає спільної скоординованої діяльності багатьох фахівців (терапевтів, хірургів-травматологів, фрізіотерапевтів, фрахівців з фрізичної реабілітації, психологів, тренерів 3 видів спорту тощо), а також використання різних лікувально-відновних і адаптаційно-тренувальних засобів. Чим вони різноманітніші, тим вища їх ефективність, оскільки вони діють на різні механізми регуляції організму спортсмена (гуморальні, імунні, нервові, функціональні) і тим більша ймовірність «влучити в ціль». До них належать широкий спектр фізіотерапевтичних і бальнеологічних засобів, різні модифікації масажу, ортопедичні засоби, механотерапія, фрункціональне тренування та ін.

Фізична реабілітація спортсменів з травмами нижніх кінцівок $є$ багатогранним завданням, тому що вимагає, з одного боку, максимально швидкого повернення до тренувальної та змагальної діяльності, а з іншого - максимально ефективного і повного відновлення рухової функції травмованої кінцівки з урахуванням підвищених профресійних вимог до рівня функціонування опорно-рухового апарату. Крім того, на завершальному етапі відновного процесу спортсменів поряд із традиційними засобами фрізичної реабілітації використовуються різні групи фрізичних вправ, які за своїм обсягом, інтенсивністю та специфрікою наближаються до тренувальних.

Під час дослідження проблеми застосування в комплексних програмах орізичної реабілітації найбільш раціональних засобів фрізичної реабілітації нами було враховано особливості досліджуваного контингенту, а саме:

1) спортсменам порівняно 3 неспортсменами притаманні великі компенсаторні можливості 


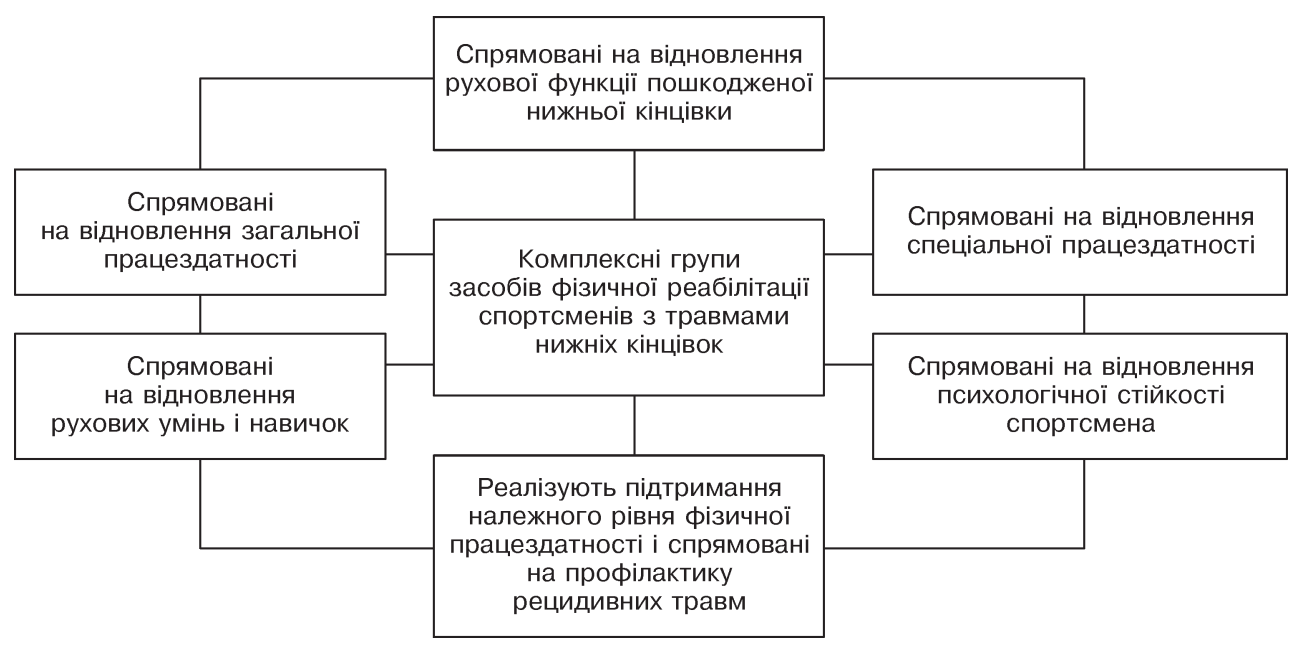

Рисунок 1 - Комплексні групи засобів фрізичної реабілітації спортсменів з травмами нижніх кінцівок

організму і більш інтенсивний перебіг адаптаційних реакцій;

2) знання, вміння і навички, набуті в процесі тренувальної діяльності, дозволяють спортсменам ефективно використовувати засоби фрізичної реабілітації в період вимушеного зниження мобільності травмованої кінцівки;

3) спортсмени зацікавлені в якнайшвидшому відновленні, враховуючи контрактні зобов'язання, тому вони більш дисципліновані під час виконання призначеного рухового режиму.

Застосування різних засобів фрізичної реабілітації має комплементувати з характером перебігу репаративних процесів пошкоджених тканин і завданнями, що стоять на певному етапі і періоді відновлення, а також з урахуванням індивідуальної реакції організму спортсмена. Ґрунтуючись на даних спеціальної науково-методичної літератури вітчизняних і зарубіжних авторів [2, 5, 15, 16], нами було сорормовано й адаптовано для спортсменів з травмами нижніх кінцівок комплексні групи засобів фрізичної реабілітації залежно від спрямованості їх дії (рис. 1).

До складу цих груп увійшли такі комплекси:

1. Комплекс засобів, спрямоВаних на Відновлення рухової функціі травмованої нижньої кінці८ки. Найважливішим засобом фрізичної реабілітації $€$ фрізичні вправи, застосування яких покликане сприяти:

- поліпшенню крово- та лімфрообігу, а також тканинного обміну в ділянці пошкодження;

- посиленню репаративних процесів у пошкоджених тканинах нижньої кінцівки;

- збільшенню обсягу рухів у суглобах травмованої кінцівки;

- зміцненню м'язово-зв' язкового апарату травмованої кінцівки та хребта;

- відновленню навички ходьби;
- підвищенню ффункціонального стану організму в цілому.

Крім того, використання в комплексі відновних заходів фрізіотерапевтичних процедур (магнітотерапія, електроміостимуляція), різних видів масажу, гідрокінезотерапії, механотерапії сприяє прискоренню процесів регенерації та відновлення рухової функції.

2. Комплекс засобів, спрямоВаних на відновлення загальної фізичної працездатності. Основними засобами $є$ фрізичні вправи, різні за формою і спрямованістю: дихальні, загальнорозвиваючі, статичні, динамічні, на розтягнення, з предметами і на снарядах. Для забезпечення тренувального ефекту дозування таких вправ повинно поступово зростати.

3. Комплекс засобіВ, спрямованих на Відновлення спеціальної фізичної працездатності. Провідне місце займають вправи на зміцнення постуральних м'язів, відновлення циклічних локомоцій, специфрічних фрізичних якостей.

4. Комплекс засобів, спрямоВаних на Відновлення рухових умінь і наВичок. Найважливішим серед них $€$ імітаційні вправи, які дозволяють зберегти схему спеціальної вправи, виконуючи ії без виражених зусиль і в помірному темпі. Виконуючи імітаційні вправи, спортсмен набуває необхідної психологічної стійкості, відновлює специфічні рухові навички. Важливе місце у відновленні спеціальних рухових умінь і навичок займають заняття на ігрових тренажерах і ігрових стендах.

5. Комплекс засобів, спрямованих на Відновлення психологічної стійкості спортсмена. Засоби психологічної реабілітації необхідно використовувати протягом усього відновного процесу з метою прискорення нормальної психологічної адаптації спортсмена до нової життєвої ситуації, адекватного сприйняття спортсменом комплексу заходів фрізичної реабілітації, 
формування здорових психологічних установок i подолання невротичних реакцій на свій стан. До засобів психологічної спрямованості відносять ідеомоторні вправи, що дозволяють подумки виконувати напруження в різних м'язових групах і образно уявляти виконання рухових дій, характерних для обраного виду спорту. Крім того, необхідно використовувати аутогенне тренування, спрямоване на зниження больових відчуттів у травмованій нижній кінцівці.

6. Комплекс засобів, що реалізує підтримання належного рівня фізичної працездатності i профолактику рецидиВних траљм. Методика і тактика використання різних засобів і методів відновного характеру ґрунтуються на загальних закономірностях розвитку втоми і відновлення у спортсменів в різні періоди тренувального процесу. Засоби, що входять в дану групу, включають: раціональне планування занять лікувальною гімнастикою відповідно до фрункціональних можливостей опорно-рухового апарату; раціональну побудову окремого заняття лікувально-тренувальної спрямованості (індивідуальна розминка, співвідношення загальнорозвиваючих і спеціальних вправ, підбір інвентарю та місць проведення занять, вправ для активного відпочинку і розслаблення, створення позитивного емоційного фону); варіювання інтервалів відпочинку між окремими вправами, заняттями.

Таким чином, комплексний вплив на різні аспекти відновлення спортсмена з травмами нижніх кінцівок дозволяє підвищити ефективність застосовуваних програм фрізичної реабілітації, знизити строки непрацездатності та досягти якісних змін у процесі одужання. Комплексна програма

\section{Література}

1. Арьков В. В. Компенсаторные механизмы нервно-мышечного дисбаланса у спортсменов высокой квалификации / М. Н. Алфимов, Т. Ф. Абрамова, В. В. Арьков, Т. М. Никитина // Биомедицина. - 2011. № 2. - C. 58-65.

2. Валеев Н. М. Восстановление работоспособности спортсменов после травм опорно-двигательного аппарата / Н. М. Валеев. - М.: Физ. культура, 2009. - 304 с.

3. Инагамджанов Т. И. Реабилитация больных при повреждениях коленного сустава / Т. И. Инагамджанов // Спорт. травма. - 2011. - № 5 C. $28-35$.

4. Иорданская Ф. А. Мониторинг здоровья и функциональная подготовленность высококвалифицированных спортсменов в процессе учебнотренировочной работы и соревновательной деятельности / Ф. А. Иорданская. - М.: Сов. спорт, 2010. - 183 с.

5. Калинкин Л. А. Реабилитация спортивных травм конечностей / Л. А. Калинкин, В. В. Арьков, О. Н. Миленин // Медицина и спорт. - 2010. № 4. - C. 27-28.

6. Капустина Н. В. Влияние посттравматической хондропатии на функциональное состояние коленных суставов у спортсменов игровых видов спорта / Н. В. Капустина, А. В. Смоленский // Лечеб. физ. и спорт. медицина. - 2013. - № 9. - С. 16-22. відновлення закінчується тоді, коли оцінка функціональних результатів відповідає вимогам спортсмена до рівня рухових можливостей і його особистим уявленням про якість життя.

\section{Висновки}

1. У загальній структурі травматизму спортивні травми становлять від 10 до 17 \% всіх пошкоджень. Пошкодження опорно-рухового апарата у спортивній практиці дуже різноманітні і зазвичай вимагають диференційованого підходу у визначенні тактики лікування і подальшого відновного процесу. Дані сучасних досліджень свідчать, що спортсмени у різних видах спорту найчастіше пошкоджують нижні кінцівки.

2. Сучасна патогенетично-обгрунтована фрізична реабілітація спортсменів з травмами опорно-рухового апарату нижніх кінцівок насамперед має бути забезпечена поєднаним застосуванням різних способів консервативного й оперативного лікування і диференціюватися залежно від локалізації травми, її механізму, характеру пошкодження, термінів репаративної регенерації травмованих тканин, періоду відновлення, віку, статі, спортивного стажу, а також специфіки обраного виду спорту.

3. Комплексний вплив на різні аспекти відновлення спортсмена з травмами нижніх кінцівок дозволяє підвищити ефективність застосовуваних програм фрізичної реабілітації, знизити строки непрацездатності та досягти якісних позитивних змін у процесі одужання.

Перспективи подальших досліджень полягають у розробленні сучасної технології фрізичної реабілітації спортсменів ігрових видів спорту 3 травмами нижніх кінцівок.

\section{References}

1. Arkov, V.V., Alfimov, M.N., Abramova, T.F., Nikitina, T.M. (2011) Kompensatornyye mekhanizmy nervno-myshechnogo disbalansa u sportsmenov vysokoy kvalifikatsii [Compensatory mechanisms neuromuscular imbalance in highly skilled athletes]. Biomeditsina - Biomedicine, 2, 58-65 [in Russian].

2. Valeev, N.M. (2009). Vosstanovleniye rabotosposobnosti sportsmenov posle travm oporno-dvigatel'nogo apparata [Restoration of sportsmen after injuries of the musculoskeletal system]. Moscow: Fizicheskaya kultura [in Russian].

3. Inagamdzhanov, T.I. (2011). Reabilitatsiya bol'nykh pri povrezhdeniyakh kolennogo sustava [Rehabilitation of patients with injuries of the knee joint]. Sportivnaya travma - Sports injury, 5, 28-35 [in Russian].

4. Iordanskaya, F.A. (2010). Monitoring zdorov'ya i funktsional'naya podgotovlennost' vysokokvalifitsirovannykh sportsmenov $v$ protsesse uchebno-trenirovochnoy raboty i sorevnovatel'noy deyatel'nosti [Monitoring the health and functional preparedness of elite athletes in the process of training work and competitive activities]. Moscow: Sovetskiy sport [in Russian].

5. Kalinkin, L.A., Arkov, V.V., Milenin, O.N. (2010). Reabilitatsiya sportivnykh travm konechnostey [Rehabilitation of sports injuries of extremities] Meditsina i sport-Medicine and Sports, 4, $27-28$ [in Russian]. 
7. Миленин О. Н. Спортивные травмы коленного сустава / О. Н. Миленин // Медицина и спорт. - 2008. - № 2. - С. 25-27.

8. Перова Е. И. Физическая реабилитация после травм как условие повышения качества жизни спортсменов: автореф. дис. ... канд. пед. наук / Е. И. Перова. - М., 2009. - 25 с

9. Платонов В. Н. Общая теория подготовки спортсменов в олимпийском спорте / В. Н. Платонов. - К.: Олимп. лит., 2004. - 808 с.

10. Самойлов В. В. Реабилитация больных после артроскопии коленного сустава / В. В. Самойлов, М. В. Бубенко, В. С. Ермаков // Скорая мед. помощь. - 2010. - № 3. - С. 73-75.

11. Шевелева Н. И. Профилактика спортивного травматизма / Н. И. Шевелева, Т. А. Макарова, Ж. С. Байшулаков. - К., 2011. - 52 с.

12. Anderson M. J. The relationships among isometric, isotonic and isokinetic concentric and eccentric quadriceps and hamstring force and three components of athletic performance / M. J. Anderson // J. of orthopedic sport and physical therapy. - 2005. - N 3. - P. 114-120.

13. Andrews J. R. Physical rehabilitation of the injured athlete / J. Andrews, G. Harrelson, K. Wilk. - W. B. Saunders, 2012. - 693 p.

14. Edson C. Postoperative rehabilitation of the multiple-ligament reconstructed knee / C. Edson // Oper. Tech. Sports Med. - 2011. - N 11. - P. 294 301.

15. Fu F. H. Sports injuries: mechanisms, prevention, treatment / F. H. Fu. - N. Y., 2004. - P. 153-187

16. Harrelson L. H. Knee rehabilitation / L. H. Harrelson // Physical rehabilitation of the injured athlete. - N. Y., 2011. - P. 267-343.

17. Hootman J. M. Epidemiology of Collegiate Injuries for 15 Sports: Summary and Recommendations for Injury Prevention Initiatives / J. M. Hootman, R. Dick, J. Agel // Athl. Train. - 2007. - N 2. - P. 311-319.

18. Kern-Steiner R. Strategy of exercise prescription using an unloading technique for functional rehabilitation of an athlete with an inversion ankle sprain / R. Kern-Steiner, H. S. Washecheck, D. D. Kelsey // J Orthop. Sports Phys. Ther. - 2010. - N 5. - P. 282-287.

19. Michael G. The effect of a 6-week plyometric training program agility / G. Michael // J. of Sports Sci. and Med. - 2010. - N 9. - P. 459-465.

20. Reeser J. C. Strategies for the prevention of volleyball related injuries / J. C. Reeser, E. H. Verhagen, W. W. Briner, T. I. Askeland, R. C. Bahr // Br. J. Sports Med. - 2012. - N 4. - P. 594-600.

21. Schneider S. Sports injuries: population based representative data on incidence, diagnosis, sequelae, and high risk groups / S. Schneider, B. Seither, S. Tonges, H. Schmitt // Br. J. Sports Med. - 2013. - N 6. - P. 334-339.

shadi_raul@hotmail.com
6. Kapustina, N.V., Smolenskiy, A.V. (2013). Vliyaniye posttravmaticheskoy khondropatii na funktsional'noye sostoyaniye kolennykh sustavov u sportsmenov igrovykh vidov sporta [Influence of post-traumatic chondropathy on the functional state of the knee in athletes playing sports]. Lechebnaya fizkultura i sportivnaya meditsina - Therapeutic physical training and sports medicine, 9, 16-22 [in Russian]

7. Milenin, O.N. (2008). Sportivnyye travmy kolennogo sustava [Sports injuries of the knee joint]. Meditsina i sport - Medicine and Sports, 2, 25-27 [in Russian].

8. Perova, E.I. (2009). Fizicheskaya reabilitatsiya posle travm kak usloviye povysheniya kachestva zhizni sportsmenov [Physical rehabilitation after injury as a condition for improving the quality of life of athletes]. Extended abstract of Candidate's thesis. Moscow [in Russian]

9. Platonov, V.N. (2004). Obshchaya teoriya podgotovki sportsmenov v olimpiyskom sporte [The general theory of training of athletes in Olympic sports]. Kiev: Olympiyskaja literatura [in Russian].

10. Samoylov, V.V., Bubenko, M.V. Yermakov, B.C. (2010). Reabilitatsiya bol'nykh posle artroskopii kolennogo sustava [Rehabilitation of patients afte knee arthroscopy]. Skoraya meditsinskaya pomosch - Emergency, 3, 73 75 [in Russian].

11. Sheveleva, N.I., Makarova, T.A., Bayshulakov, Zh.S. (2011). Profilaktika sportivnogo travmatizma [Prevention of sports injuries]. Karaganda [in Russian].

12. Anderson, M.J. (2005). The relationships among isometric, isotonic and isokinetic concentric and eccentric quadriceps and hamstring force and three components of athletic performance. Journal of orthopedic sport and physical therapy, 3, 114-120.

13. Andrews, J.R., Harrelson, G., Wilk, K. (2012). Physical rehabilitation of the injured athlete. W. B. Saunders.

14. Edson, C. (2011). Postoperative rehabilitation of the multiple-ligament reconstructed knee. Oper. Tech. Sports Med., 11, 294-301.

15. Fu, F.H. (2004). Sports injuries: mechanisms, prevention, treatment. New York, 153-187.

16. Harrelson, LH. (2011). Knee rehabilitation. Physical rehabilitation of the injured athlete. New York, 267-343.

17. Hootman J.M., Dick, R., Agel, J. (2007). Epidemiology of Collegiate Injuries for 15 Sports: Summary and Recommendations for Injury Prevention Initiatives. Athl. Train., 2, 311-319.

18. Kern-Steiner, R., Washecheck, H.S., Kelsey, D.D. (2010). Strategy of exercise prescription using an unloading technique for functional rehabilitation of an athlete with an inversion ankle sprain. J Orthop. Sports Phys. Ther., 5 282-287.

19. Michael, G. (2010). The effect of a 6 -week plyometric training program agility. Journal of Sports Science and Medicine, 9, 459-465.

20. Reeser, J.C., Verhagen, E.H., Briner, W.W., Askeland, T.I., Bahr, R.C (2012). Strategies for the prevention of volleyball related injuries. Br. J. Sports Med., 4, 594-600.

21. Schneider, S., Seither, B., Tonges, S., Schmitt, H. (2013). Sports injuries: population based representative data on incidence, diagnosis, sequelae, and high risk groups. Br. J. Sports Med., 6, 334-339.

Надійшла 28.10.2017 